\title{
DOES OPEN-PLAN OFFICE ENVIRONMENT SUPPORT CREATIVITY? THE MEDIATING ROLE OF ACTIVATED POSITIVE MOOD
}

\author{
Szu-Yin LIN $^{1 *}$, Hsin-I CHANG ${ }^{2}$ \\ ${ }^{1}$ National Kaohsiung University of Science and Technology, Office of Research and Development \\ No. 415, Jiangong Rd., Sanmin Dist., Kaohsiung City 80778, Taiwan \\ ${ }^{2}$ National Sun Yat-sen University, Institute of Human Resource Management No. 70, Lien-hai Rd., \\ Gushan Dist., Kaohsiung City 80424, Taiwan
}

Received 16 May 2019; accepted 5 November 2019

\begin{abstract}
This study examines how perceived physical office environment features affect occupants' creativity through positive moods. Based on a sample of 181 occupants in open-plan offices, we found that perceived spatial organization features had a positive relationship with occupants' self-assessed creativity, and this relationship is mediated by positive moods. Although perceived architectonic details of the physical work environment do not have a direct effect on occupants' creativity, there is also a mediating effect through positive moods. A further examination revealed that activated positive mood significantly mediates the relationship between both physical work environment features and occupants' creativity, whereas deactivated positive mood was not significant as a mediator. When occupants perceived the physical work environment to be supportive in providing various workspaces and is well decorated, it is most likely to enhance creativity.
\end{abstract}

Keywords: activated positive mood, creativity, moods, physical work environment.

\section{Introduction}

Nowadays, the changing nature of work and economy has largely impacted working conditions and job requirements (Duffy, 1997; Ree, 2002; McElroy \& Morrow, 2010). In the knowledge-based economy today, creativity is recognized as one of the most important abilities at work that contributes to firm competitiveness (Florida, 2002; Mumford \& Licuanan, 2004; Shalley \& Gilson, 2004; Zhang \& Bartol, 2010). Although creativity has been conceptualized as a variety of definitions, it is generally defined as the ability to produce novel (original and unique) and useful work, including generating ideas or solutions to new products, services and processes (Amabile, 1988; Runco \& Jaeger, 2012; Sternberg \& Lubart, 1996). Different factors contribute to a person's creative potential, empirical studies have focused

*Corresponding author. E-mail: lin.sy1104@gmail.com 
on factors such as personal characteristics (e.g. Barron, 1969; Guilford, 1967; MacKinnon, 1962; Torrance, 1966); social environments that foster creativity (e.g. Amabile, 1988; Amabile \& Gryskiewicz, 1989; Stokols, Clitheroe, \& Zmuidzinas, 2002); leadership that promotes creativity in teams and individuals (e.g. Jung, 2001; Shin \& Zhou, 2003; Sosik, 1997; Sosik, Kahai, \& Avolio, 1998); and affective states influencing creativity (e.g. Baas, Dreu, \& Nijstad, 2008). Beyond these factors, the physical work environment is also observed to support creativity (Dul, Ceylan, \& Jaspers, 2011; Haner, 2005; Kristensen, 2004).

Physical work environment is the space an organization provides to support its employees to carry out their work activities (Davis, Leach, \& Clegg, 2011). The forms and designs of physical work environment have also transformed through time (Ree, 2002), from closed offices, cubicles, to open-plan or more flexible arrangements, each provides different behavioral and performance outcomes. In recent years, a number of visually stunning and impressive office designs were introduced, especially popular among tech companies, however, the link between physical work environment and creativity is yet to be explored (Dul et al., 2011). Since the effects of physical environment on creativity is less direct than other factors (Hemlin, Allwood, \& Martin, 2008), thus far, researchers and managers alike have a very limited understanding of how it affects creativity at work (Dul et al., 2011; McElroy \& Morrow, 2010).

The impact of physical work environment features on work performance is not a new issue. Since the Hawthorne studies, researchers have been trying to investigate how the external work environment affects work outcomes (Elsbach \& Pratt, 2007; May, Oldham, \& Rathert, 2005; McElroy \& Morrow, 2010; Thompson, 2003). Past research have examined the effects of window views, plants, lightings, posters or pictures and colors in the office (Hedge, 1982; Kaye \& Murray, 1982; Küller, Ballal, Laike, Mikellides, \& Tonello, 2006; Kwallek \& Lewis, 1990; Mitchell McCoy \& Evans, 2002; Steidle \& Werth, 2013; Stone \& Irvine, 1994; Rompay \& Jol, 2016), results indicated that these elements are associated with office occupants' perception and mood (Knez, 2001; Leather, Beale, Santos, Watts, \& Lee, 2003) and affects their behavior (Gifford, 1988; Mattila \& Wirtz, 2001). Previous research also showed that the physical work environment affects both job satisfaction and performance (May et al., 2005; Vischer, 2007), work environments can also reflect organizational culture (T. J. Kallio, K.-M. Kallio, \& Blomberg, 2015); affect employee attitudes (Turner Parish, Berry, \& Lam, 2008), idea generation (Magadley \& Birdi, 2009) and innovation (Kelley \& Littman, 2005; Moultrie et al., 2007; Oksanen \& Ståhle, 2013, p. 210). However, to date, there is still a lot to explore on the relationship between physical work environment and its effect, especially how it relates to creativity (e.g. Leonard \& Swap, 1999, p. 137; Dul et al., 2011; Haner, 2005; Sailer, 2011).

As creativity can be examined through different angles, previous studies suggested that a multivariate approach can provide a more comprehensive view on how different attributes converge to yield creative outcome (Caroff \& Lubart, 2012; Lubart \& Guignard, 2004). In this research, we based on the multivariate approach (Lubart, 2003; Sternberg \& Lubart, 1995), which incorporate cognitive (e.g. information-processing abilities), conative (personality, motivation), emotional (state and trait), and environmental (physical and social) factors in the prediction of creativity. We specifically take on the emotional and environmental components for examining how it relates to creativity in an empirical setting. Furthermore, we adopted 
the valence and arousal circumplex model of affect (Russell, 1980, 2003) to extend our knowledge on the potential role of moods in the physical work environment - creativity relationship. We also believe that there is practical importance to explore the impact of physical work environment on its incumbents. According to Janetta Mitchell McCoy (2005), the cost of the physical work environment in an office accounts for the 2nd highest financial overhead among all resources in organizations. Nowadays, open-plan office design has become the most popular solution for knowledge workers, given its advantage in lower costs and the possibility to promote teamwork and collaboration (Greene \& Myerson, 2011). The aim of this study is to add to the accumulating literature that explores the relationship between open-plan office environment and mood, and how they enhance creativity for knowledge workers. The results of this research are expected to provide insights into ways of governing and maximizing real estate costs for efficient use of the physical work environment. To do so, we first review past literature linking physical work environment with employee creativity, and then we examine the mechanism through which the physical work environment can enhance employee creativity, and explore the possible influence of moods. Finally, we provide implications on how certain features in the physical work environment relates to creativity.

\section{Physical work environment and creativity}

Physical work environment plays a central role in the work experience; for knowledge workers, most of the job-related tasks are performed in the office, how an office environment is designed can affect occupants' feelings and behavior (Vischer, 2008), and a work environment should meet employee skills and abilities in order to produce creativity and flow (Csikszentmihalyi, 2003). Creativity involves the production, conceptualization, or development of novel and useful ideas, processes, or procedures by an individual or by a group of individuals working together (Amabile, 1988; Shalley, 1991; Shalley, Gilson, \& Blum, 2000), it is a behavior resulting from particular constellations of personal characteristics, cognitive abilities and social environments (Amabile, 1983). Mitchell McCoy (2005) identified several features in the physical work environment that facilitates creativity, which is spatial organization that includes the level of enclosure, territoriality, size, shape, allocation and division of space; architectonic details encompass fixed or stationary aesthetics of the place, ornaments or materials intended to embellish the environment, including decorative styles, colors and artwork; views are the observable features visible from the work area; resources refer to the accessibility to and functional characteristics of equipment and services that support occupants' use of the environment; and ambient conditions include illumination, heating, ventilation, and acoustics in the environment. Among these features, spatial organization and architectonic details are the two elements embedded in the physical configuration and furniture layouts of a work environment and may be more prominent in influencing occupants' satisfaction performance (Brill, Margulis, \& Konar, 1984; 1985; Jo Hatch, 1987; Sullivan, 1991; Vischer, 1989, 2007), dimensions of a setting's spatial configuration may impact individuals' creativity (Aiello, DeRisi, Epstein, \& Karlin, 1977; Shalley \& Oldham, 1997; Shalley, Zhou, \& Oldham, 2004). While resources, views and ambient conditions are additional objects or features that are less permanent elements in the workspace. 
Hermen Jan van Ree (2002) proposed that providing work environments that support various tasks and activities can increase the effectiveness of the physical workspace, and the interior design, furnishing and colors can be influential to organizational creativity. Tomi J. Kallio's, Kirsi-Mari Kallio's, and Annika Johanna Blomberg's (2015) case study supports this view; they found that both spatial organization and architectonic details within the physical space shapes organizational culture and fosters creativity. For spatial organization, certain workspace designs foster social interaction, which contributes to knowledge sharing (Coradi, Heinzen, \& Boutellier, 2015) and problem-solving (Becker \& Steele, 1990, 1995; Steele, 1986; Zelinsky, 1998). Despite receiving less attention, the aesthetic dimension of physical space and office design is found related to occupants' sensory experience (Elsbach \& Pratt, 2007), and it is speculated that a cue-rich environment to a certain extent may stimulate creativity than more barren ones (Sternberg \& Lubart, 1995). Therefore, we propose the following hypothesis:

Hypothesis 1a: Perceived spatial organization the physical work environment is positively related to occupants' creativity.

Hypothesis 1b: Perceived architectonic details of the physical work environment is positively related to occupants' creativity.

\section{The mediating role of mood}

Organizations are affectively laden environments (Amabile, Barsade, Mueller, \& Staw, 2005), the stream of affective experience that includes both positive mood and negative mood states are referred to as mood at work (Fisher \& Ashkanasy, 2000; Watson, 2000; Weiss, 2002). Previous studies have shown that features in the physical work environment such as colors and window views may have a positive influence on occupants' mood (e.g. Küller et al., 2006; Küller \& Mikellides, 1993); the presence of plants or windows facilitates positive mood (Hedge, 1982; Kaye \& Murray, 1982; Larsen, Adams, Deal, Kweon, \& Tyler, 1998); also, the ergonomic support of office environments affects the wellbeing of people (S. Kaplan \& R. Kaplan, 2009; Kristensen, 2004; Stone \& English, 1998; Stone \& Irvine, 1994), and it should be adaptable and supportive to optimize comfort and manage workspace stress successfully in order to reach desirable performance outcomes (Vischer, 2007, 2008).

Moods are observed to be a number of organizational work outcomes including creativity (Amabile et al., 2005; George \& Zhou, 2007; Hennessey \& Amabile, 2010; Madrid, Patterson, Birdi, Leiva, \& Kausel, 2014), and the link between mood and creativity was reported to be consistent (Baas et al., 2008; Dreu, Baas, \& Nijstad, 2008). Both positive moods and negative moods are reported to enhance creativity (Amabile, 1996; Dreu et al., 2008; George \& Zhou, 2002; Hao, Xue, Yuan, Wang, \& Runco, 2017; Isen, 2000; Isen, Daubman, \& Nowicki, 1987). Positive affect leads to greater cognitive flexibility and facilitates creative problem solving across a broad range of settings (Ashby, Isen, \& Turken, 1999), people in a positive mood are more likely to have richer associations within existing knowledge structures, and thus are likely to be more flexible and original, they tend to be more creative (Lyubomirsky, King, \& Diener, 2005; Staw, Sutton, \& Pelled, 1994). Individuals in positive mood states have been reliably shown to be more creative on a range of tasks (Hirt, 1999). On the other hand, a substantial amount of literature suggesting that negative affect can also have a facilitative effect on creativity, for 
example, Jennifer M. George and Jing Zhou (2002) contend that negative mood can cause individuals to be more critical and discerning, which lead them to produce novel and useful ideas.

Meta-analysis results suggest that positive moods enhance creative thinking; and the positive-mood-enhances creativity generalization is more robust when compared to neutralmoods rather than to negative moods (Baas et al., 2008; Davis, 1984). In addition to the positive-negative valence distinction, researchers proposed another dimension that describes the activation or arousal resulting in the circumplex model of affect (Feldman Barrett \& Russell, 1998; Larsen \& Diener, 1992; Russell, 1980, 2003; Tellegen, Watson, \& Clark, 1999). Moods can be understood as a linear combination of these two dimensions, or as varying degrees of both valence and activation. Activation refers to the "readiness for action or energy expenditure" (Russell, 2003, p. 156), activating mood states (i.e., anger, fear, happiness) and deactivating mood states (i.e., calm, relaxed, sad, depressed) can differentially affect creative performance. Activating moods are believed to enhance more creativity than deactivated ones (Dreu et al., 2008; Madrid et al., 2014), as they impact creativity is different ways: positive activating moods lead to creative performance through enhanced cognitive flexibility and inclusiveness, whereas negative activating moods lead to creative performance through enhanced cognitive perseverance and persistence.

On the other hand, space refers to aspects of reality that involve concepts of distance, height, width, breadth, orientation, and direction, and also human perceptions, constructions, and uses of these aspects (Berquist, 1999); many experiences and emotions are attributed to physical space (Baldassare, 1978). Ideally, physical work environments should be low-stress and comfortable (Vischer, 2007), and supports cognition and creative thinking (Haner, 2005; Kristensen, 2004; Martens, 2011). Positive mood states can be considered as a mediator for contextual characteristics in the workplace and employee creativity (Shalley et al., 2004). Hence, we propose that moods will mediate the relationship between physical work environment features and creativity, and such effects are stronger for activated positive mood compared to deactivated positive mood. Consequently:

Hypothesis 2a: Positive moods will mediate the relationship between perceived spatial organization and occupants' creativity.

Hypothesis 2b: Positive moods will mediate the relationship between perceived architectonic details and occupants' creativity.

Hypothesis 3a: The mediation effects of activated positive moods between perceived spatial organization and occupants' creativity will be stronger compared to deactivated positive moods.

Hypothesis 3b: The mediation effects of activated positive moods between perceived architectonic details and occupants' creativity will be stronger compared to deactivated positive moods.

\section{Methods}

\subsection{Participants and procedure}

Surveys were distributed via emails and printed forms to a heterogeneous sample of full-time employees. We first identified knowledge intensive organizations that emphasize creativity as 
their core value, then we contacted potential companies for their willingness to participate in the study, we also asked our contact person to identify if their physical work environment is based on open-plan office designs. Then we asked them to refer our questionnaire to their employees.

A total of 193 participants from 138 different companies filled out the questionnaire, 12 were eliminated because of incomplete responses and inappropriate response sets, yielding 181 valid samples. Among them 58.6\% were female, the mean age is between $26-30$ years, the average tenure is 42.4 months, and the majority of respondents held a bachelor's degree (63.0\%), 34.8\% received a master's degree. Participants work in a variety of departments, including $19.3 \%$ from sales and marketing, $11.6 \%$ from planning, $10.5 \%$ from customer services, $9.9 \%$ from research and development, $9.9 \%$ from the administration, $8.3 \%$ from human resources, and $6.6 \%$ from the creative department. Other participants were from manufacturing (5\%), finance and accounting (4.4\%), information technology (3.9\%), quality control $(2.2 \%)$, procurement $(2.2 \%)$, law (1.7\%) and others $(4.4 \%)$.

\subsection{Instruments}

\subsubsection{Physical work environment features}

The physical work environment is defined as the settings allocated for work. Since there are no suitable instruments measuring perceived spatial organization and perceived architectonic details of the physical work environment, we developed a 7-item scale based on the environmental features proposed by Ree (2002) and Mitchell McCoy (2005). Ree (2002) proposed several performance criteria for effective and creative office accommodation. According to his description, we generated 7 items. The items were intended to measure the perceived spatial organization and perceived architectonic details, which are two of the physical work environment features proposed by Mitchell McCoy (2005). Participants were asked to evaluate their own work environment settings based on a 5-point Likert scale, ranging from 1 (strongly disagree) to 5 (strongly agree). The items were listed in Appendix.

To validate our scale, we first conducted exploratory factor analysis using Mplus 7.4 (L. K. Muthén \& B. O. Muthén, 1998), with maximum likelihood estimation and geomin rotation suggests that 2 -factor model is the best fit $\left(\chi^{2}(8)=14.551, \mathrm{p}=0.69\right.$, CFI $=.98$, TLI $=$ .94 , RMSEA $=.067$, SRMR $=.034$ The two dimensions are perceived spatial organization (4 items, $\alpha=.67$ ) and perceived architectonic details (architectonic details, 3 items, $\alpha=.66$ ). Based on the 2-factor model extracted, we conducted confirmatory factor analysis. Results showed good fit for the model $\left(\chi^{2}(13)=22.214, \mathrm{p}=0.052\right.$, CFI $=.97$, TLI $=.94$, RMSEA $=$ $.063, \mathrm{SRMR}=.042)$.

\subsubsection{Mood}

Employee mood was measured using the Job affect scale developed by Brief, Burke, George, Robinson, and Webster (1988). The Job affect scale is a 20 -item self-report instrument that measures two orthogonal, bipolar mood dimensions. Although the positive mood and negative mood states measured in the Job affect scale are similar to the Positive and negative affect schedule, Job affect scale covers more mood states than the Positive and 
negative affect schedule. Empirical studies asserted that the four factors used in Job affect scale could best represent affect (Burke, Brief, George, Roberson, \& Webster, 1989; Saavedra \& Earley, 1991).

In the current study, we conduct our analyses with the four-factor model. The Job affect scale dimensions reflect both hedonic valence and activation. Respondents were asked to rate how they felt working in the current work environment over the past week based on a 5 -point Likert scale, ranging from 1 (strongly disagree) to 5 (strongly agree). Confirmatory factor analysis results indicated better fit for four dimensions $\left(\chi^{2}(146)=324.84, \mathrm{p}<.00^{\star * *}\right.$, $\mathrm{CFI}=.89$, TLI $=.87, \mathrm{RMSEA}=.08, \mathrm{SRMR}=.07)$, compared to the traditional two-factor model of positive and negative affect $\left(\chi^{2}(151)=669.85, \mathrm{p}<.00^{\star * *}, \mathrm{CFI}=.67\right.$, TLI $=.63$, RMSEA $=.14$, SRMR $=.12$ ). The four factors in the dimension are relaxation (4 items, $\alpha=.80$ ); enthusiasm ( 5 items, one item was deleted because of high cross loading, $\alpha=0.86$ ); fatigue ( 4 items, $\alpha=0.79$ ); and nervousness (6 items, $\alpha=0.85$ ).

\subsubsection{Creativity}

Creativity is measured by the 13 -item scale developed by Zhou and George (2001). This scale is a general measure of creative behavior in the workplace, respondents rate the extent to which these behavior character themselves on a five-point Likert scale, ranging from 1 (not at all characteristic) to 5 (very characteristic).

Although the original questionnaire was designed for supervisor rating, we asked our participants to rate themselves according to the items, which is the extent to which employees perceive that they produce new and potentially useful ideas. Previous empirical studies have used self-report measures to examine employees' subjective experiences of creativity (e.g. Dul et al., 2011; Janssen, 2000; Shalley, Gilson, \& Blum, 2009; Zhou, Shin, \& Cannella, 2008). Further, scholars also noted that focusing on external evaluation of creativity may overshadow creative potential (Beghetto \& Kaufman, 2009; Runco, 2004), and found correlation between supervisory and self-reported ratings of creativity (Axtell et al., 2000; Janssen, 2000), and argued that "employees are best suited to self-report creativity because they are the ones who are aware of the subtle things they do in their jobs that make them creative" (Shalley et al., 2009, p. 495).

The original scale by Zhou and George (2001) has good validity and reliability, Cronbach's alpha $-\alpha=0.96$; our results also has good validity and reliability (factor loadings between .62 to $.80 ; \alpha=.92$ ); all 13 items were aggregated for a total score.

\subsubsection{Demographic variables}

We asked participants to report their gender, age, level of education, tenure and the department of their current job. According to previous studies, the accumulation of knowledge and experiences may serve as a source of employee creativity (Amabile, 1988; Tierney \& Farmer, 2002; Woodman, Sawyer, \& Griffin, 1993), age, level of education, and tenure are often used as control variables in creativity research. As for the departments, we create dummy code each of the 14 departments ( 1 and 0 ), and then correlate the 14 departments with the dependent variable "creativity" respectively; results showed that all 14 departments were uncorrelated with creativity. Therefore, we did not include departments as a control variable further in our analyses. 


\section{Results}

\subsection{Descriptive and correlations}

Means, standard deviations and correlations are presented in Table 1. In line with our expectations, positive moods were positively correlated with perceived physical work environment features and creativity, whereas negative moods were negatively correlated with perceived physical work environment features and creativity.

Table 1. Descriptive statistics and correlation (source: created by authors)

\begin{tabular}{|c|c|c|c|c|c|c|c|c|c|c|c|c|c|c|c|}
\hline & M & SD & 1 & 2 & 3 & 4 & 5 & 6 & 7 & 8 & 9 & 10 & 11 & 12 & 13 \\
\hline 1. Gender & .41 & .494 & & & & & & & & & & & & & \\
\hline 2. Age & 2.36 & 1.05 & .044 & & & & & & & & & & & & \\
\hline 3. Education & 2.34 & .52 & .072 & $.160^{*}$ & & & & & & & & & & & \\
\hline 4. Tenure & 42.46 & 58.82 & .021 & $.636^{* *}$ & .085 & & & & & & & & & & \\
\hline $\begin{array}{l}\text { 5. Spatial } \\
\text { organiza- } \\
\text { tion }\end{array}$ & 3.47 & .76 & .110 & .069 & .092 & .097 & & & & & & & & & \\
\hline $\begin{array}{l}\text { 6. Architec- } \\
\text { tonic details }\end{array}$ & 2.83 & .89 & -.022 & .013 & .009 & .024 & $.383^{* *}$ & (.66) & & & & & & & \\
\hline $\begin{array}{l}\text { 7. Positive } \\
\text { moods }\end{array}$ & 2.84 & .57 & -.005 & .072 & .026 & .135 & $.394^{* *}$ & $.445^{\star *}$ & $(.67)$ & & & & & & \\
\hline $\begin{array}{l}\text { 8. Negative } \\
\text { moods }\end{array}$ & 2.48 & .68 & $.162^{*}$ & -.128 & -.008 & -.043 & $-.312^{* *}$ & $-.420^{* *}$ & $-.482^{* *}$ & $(.86)$ & & & & & \\
\hline $\begin{array}{l}\text { 9. Relax- } \\
\text { ation }\end{array}$ & 3.20 & .74 & -.068 & .067 & .020 & .129 & $.334^{* *}$ & $.374^{* *}$ & $.903^{* *}$ & $-.372^{* *}$ & $(.85)$ & & & & \\
\hline $\begin{array}{l}\text { 10. Enthusi- } \\
\text { asm }\end{array}$ & 2.49 & .57 & .079 & .058 & .025 & .103 & $.356^{* *}$ & $.405^{\star \star}$ & $.832^{* *}$ & $-.482^{* *}$ & $.512^{\star \star}$ & $(.80)$ & & & \\
\hline 11. Fatigue & 2.67 & .84 & $.163^{*}$ & $-.181^{*}$ & .052 & -.095 & $-.218^{* *}$ & $-.368^{* *}$ & $-.349^{* *}$ & $.856^{* *}$ & -.119 & $-.543^{* *}$ & $(.86)$ & & \\
\hline $\begin{array}{l}\text { 12. Ner- } \\
\text { vousness }\end{array}$ & 2.28 & .77 & .109 & -.030 & -.071 & .028 & $-.312^{* *}$ & $-.339^{* *}$ & $-.468^{* *}$ & $.828^{* *}$ & $-.524^{* *}$ & $-.258^{* *}$ & $.418^{* *}$ & (.79) & \\
\hline 13. Creativity & 3.47 & .63 & $.236^{* *}$ & .134 & .053 & .107 & $.283^{* *}$ & $.203^{* *}$ & $.443^{* *}$ & $-.257^{* *}$ & $.334^{\star *}$ & $.454^{* *}$ & $-.228^{* *}$ & $-.204^{* *}$ & $(.85)$ \\
\hline
\end{tabular}

- Reliability coefficients are presented along the main diagonal in parentheses.

- Correlation is significant at the 0.05 level (2-tailed).*

- Correlation is significant at the 0.01 level (2-tailed).**

- Total number of the samples $(\mathrm{N})=181$.

- Gender: 1 = male, $0=\mathrm{f}$ emale.

- Age: $1=20-25,2=26-30,3=31-35,4=36-40,5=41$ and above.

- Education: 1 = high school or under, 2 = college or university, 3 = master, $4=$ doctoral degree.

- Tenure: counted in months.

\subsection{Test of hypotheses}

To test our hypotheses, we first regress creative behavior and various mood states on the two perceived physical work environment features. We included gender, age and tenure as control variables, excluding level of education because it was not significantly correlated with the research variables in this study (all $\mathrm{p}>.10$ ). Then to test our proposed mediation effects we used Mplus 7.4 (L. K. Muthén \& B. O. Muthén, 1998), it enables us to examine indirect effects with multiple mediators with bootstrap resampling technique. 


\subsection{Effects of physical work environment features on creativity}

Path analysis results indicated that there is a significant direct effect of perceived spatial organization on creativity $(\beta=.167$, S.E. $=.062, \mathrm{p}<.01)$; but no significant direct effect of perceived architectonic details on creativity $(\beta=.091$, S.E. $=.053, \mathrm{p}=.08$ Results are shown in Table 2. Hypothesis 1a is supported; Hypothesis $1 \mathrm{~b}$ was not supported.

Table 2. Direct effects on creativity (source: created by authors)

\begin{tabular}{|l|l|c|c|c|c|}
\hline \multicolumn{1}{|c|}{ Outcome } & \multicolumn{1}{|c|}{ Predictor } & B & SE & $\mathrm{t}$ & $\mathrm{p}$ \\
\hline \multirow{3}{*}{ Creativity } & Spatial organization & .167 & .062 & 2.679 & .007 \\
\cline { 2 - 6 } & Architectonic details & .091 & .053 & 1.726 & .084 \\
\cline { 2 - 6 } & Gender & .272 & .089 & 3.070 & .002 \\
\cline { 2 - 6 } & Age & .060 & .054 & 1.109 & .267 \\
\cline { 2 - 6 } & Tenure & .000 & .001 & .201 & .841 \\
\hline Intercepts & Creativity & 2.374 & .236 & 10.065 & .000 \\
\hline Residual variance & Creativity & .339 & .036 & 9.513 & .000 \\
\hline
\end{tabular}

\subsection{Mediation effects of mood}

To test the indirect effects, we tested the hypothesized structural model by first specifying a baseline mediation model where all paths were included in the model (direct paths from perceived spatial organization and perceived architectonic details to positive moods and negative moods, from positive moods and negative moods to creativity including control variables). The model had marginal fit $(\chi 2(9)=38.20, \mathrm{CFI}=.83$, TLI $=.66$, RMSEA $=.13$, SRMR $=$ .05). Results of the path model are reported in Figure 1. Then, we adopted a bootstrap estimation method with resampling of 5000 times. Results showed significant indirect effect of both perceived spatial organization on creativity through positive moods (effect spatial organization $=.085,95 \%$ CI $[.027, .167])$; and perceived architectonic details on creativity through positive moods (effect architectonic detail $=.096,95 \%$ CI $[.051, .161]$ ). As shown in Table 3, the indirect effects through negative moods were both not significant. The results support Hypothesis $2 \mathrm{a}$ and $2 \mathrm{~b}$.

In order to examine the effects of activated and deactivated moods in detail, we conducted another path model that includes all four dimensions of the circumplex model of mood. Figure 2 shows the path model results. Table 3 shows the bootstrapping results for indirect effects. Specifically, activated positive mood "enthusiasm" mediates the relationship between perceived spatial organization and creativity (effect spatial organization $=.063,95 \%$ CI $[.015, .141])$; and perceived architectonic details and creativity (effect architectonic detail $=.072,95 \% \mathrm{CI}[.025, .148])$; other paths through relaxation, fatigue and nervousness were not significant. Hypothesis $3 \mathrm{a}$ and $3 \mathrm{~b}$ posits that the mediation effects of activated positive moods will be stronger compared to deactivated positive moods. From the results, the path of perceived spatial organization to creativity and perceived architectonic details to creativity through enthusiasm was significant, while through relaxed was not significant, thus supporting both Hypothesis $3 \mathrm{a}$ and $3 \mathrm{~b}$. 


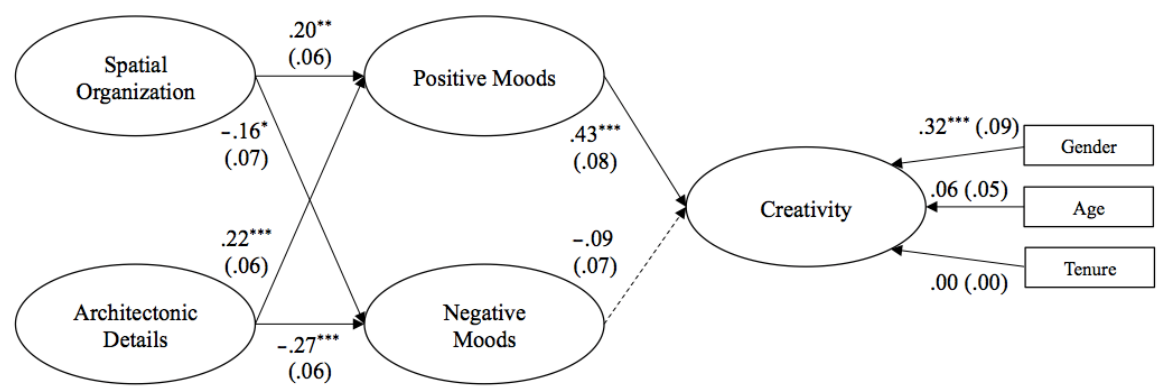

Figure 1. Model results of spatial organization, architectonic details and creativity through positive and negative moods (source: created by authors)

Table 3. Estimates of the indirect effects on creativity (source: created by authors)

\begin{tabular}{|c|c|c|c|c|c|c|c|c|c|c|c|c|}
\hline \multirow[b]{3}{*}{ Effect } & \multicolumn{6}{|c|}{ Spatial organization } & \multicolumn{6}{|c|}{ Architectonic details } \\
\hline & \multirow{2}{*}{ 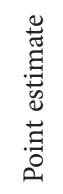 } & \multicolumn{2}{|c|}{$95 \%$ CI } & \multirow{2}{*}{ 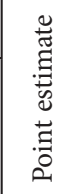 } & \multicolumn{2}{|c|}{$95 \% \mathrm{CI}$} & \multirow{2}{*}{ 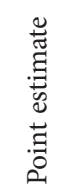 } & \multicolumn{2}{|c|}{$95 \% \mathrm{CI}$} & \multirow{2}{*}{ 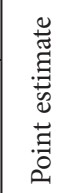 } & \multicolumn{2}{|c|}{$95 \% \mathrm{CI}$} \\
\hline & & Lower & Upper & & Lower & Upper & & Lower & Upper & & Lower & Upper \\
\hline Positive & .085 & .027 & .167 & & & & .096 & .051 & .161 & & & \\
\hline Negative & .014 & -.004 & .053 & & & & .024 & -.011 & .068 & & & \\
\hline Relaxation & & & & .027 & -.004 & .098 & & & & .030 & -.005 & .088 \\
\hline Enthusiasm & & & & .063 & .015 & .141 & & & & .072 & .025 & .148 \\
\hline Fatigue & & & & .003 & -.011 & .035 & & & & .008 & -.045 & .059 \\
\hline Nervousness & & & & .009 & -.023 & .057 & & & & .089 & -.028 & .048 \\
\hline Total effect & .099 & .041 & .179 & .102 & .036 & .177 & .120 & .064 & .189 & .120 & .059 & .193 \\
\hline
\end{tabular}

Sample size $=181$.

$\mathrm{CI}=$ bias corrected and accelerated $95 \%$ confidence interval; 5000 bootstrap samples.

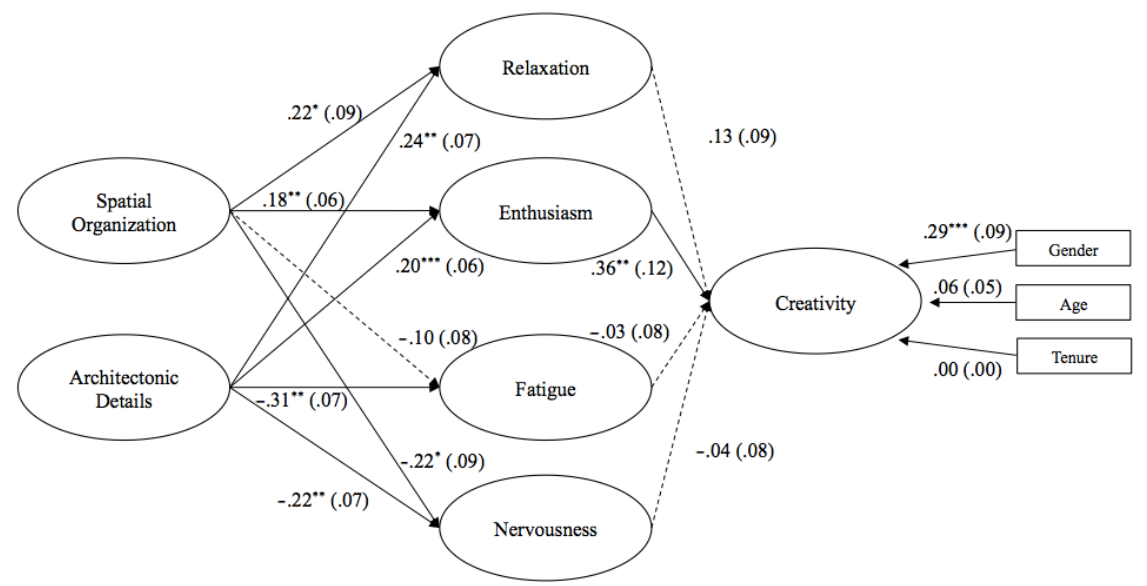

Figure 2. Model results of spatial organization, architectonic details and creativity through activated and deactivated mood (source: created by authors) 


\section{Discussion}

The results of this study support the view that physical work environment adds to the many influences on occupants' creativity (Dul et al., 2011; Haner, 2005; Kristensen, 2004; Leonard \& Swap, 1999). In line with T. J. Kallio, K. M. Kallio, and Blomberg's (2015) findings, we showed empirical evidence that perceived spatial organization and perceived architectonic details are two features in the physical work environment that play a significant role in the emergence of organizational creativity. With self-report survey data, we found a positive relationship between perceived spatial organization and occupants' creativity. Further, the relationships between both perceived spatial organization and perceived architectonic details and occupants' creativity are found mediated by activated positive mood. These results provide an understanding towards how physical environment relates to creativity for knowledge workers.

Several theoretical and practical conclusions can be drawn from the results of this study. First, when the perceived spatial organization is able to support various tasks and activities, it can foster activated positive mood and leads to creativity. The link between spatial organization and occupants' creativity can be illustrated by Mitchell McCoy's (2002) notion that spatial organization generally supports individual work process as well as team communication and collaboration, accompanied by improved organizational climate or social environment (Zalesny \& Farace, 1987) that enhances individuals' creativity.

Second, from our results, although perceived architectonic details did not have a significant direct effect on occupants' creativity, it is positively related to positive moods. Perceived architectonic details in the work environment can reflect the values and norms of the people and the organization (Brill et al., 1984), people feel more comfortable in decorated interior spaces compared with little or no architectural details (Kopec, 2006, p. 243), the use of imagery in interior design can also encourage specific behaviors (Moultrie et al., 2007).

Third, in this article we examine the relationships between mood, creativity and the physical workspace, viewing mood as a source of signals concerning states of the environment, and the attentional focus that affects behavior (Frijda, 1988). Moreover, our study also confirms the relationship between activated moods and creative behavior. We also support the previous conceptualization of circumplex model of affect (Larsen \& Diener, 1992; Russell, 1980, 2003; Watson \& Tellegen, 1985), feelings charged with activation entail attentional interest, motivational intensity, responsiveness and engagement with the environment (Madrid et al., 2014), the level of activation should be included to better explain the relationship between mood and creativity (Dreu et al., 2008), and may enrich our understanding towards the relationship between moods and both attitudinal and behavioral outcomes (Bindl \& Parker, 2012; Bissing-Olson, Iyer, Fielding, \& Zacher, 2013; Seo, Bartunek, \& Feldman Barrett, 2010; Warr, Bindl, Parker, \& Inceoglu, 2014). Finally, our research adds to the research interests paid upon physical work environment in many distinct disciplines such as sociology, organizational theory, environmental psychology, architecture and facility management (Kallio et al., 2015; Martens, 2011; McElroy \& Morrow, 2010; Sailer, 2011). Our results confirmed that the physical work environment is able to incubate creativity. 


\section{Limitations and implications for future research}

Several limitations of this study should be noted. First, a potential methodological limitation concerns the use of self-report measures. We argue that self-report can be a valid method of measuring personal perceptions and behaviors (Bissing-Olson et al., 2013; Bledow, Rosing, \& Frese, 2013; Shalley et al., 2009). Features of the physical work environment are intended to capture occupants' perception; and each occupant is best suited to provide their moods in the current work environment, as well as creative behavior. Also, user perceptions of environmental conditions are generally used to diagnose building performance and its effects (Vischer, 2008; Vischer \& Fischer, 2005). Further, since our data were collected crosssectional, the dynamic interplay of affect and creativity was not captured in the current study. Bledow's et al. (2013) study observed that the decrease of negative affect also contributes to creativity. Future studies can investigate how physical work environments regulate negative affect, and sustain positive affect in order to achieve creativity. Also, the use of multiple methods and sources of data such as experience sampling should be incorporated to better capture the variability of affect in the workplace.

The heterogeneous sample across different jobs and industries provided us with preliminary results on how physical work environment affects creativity. Nevertheless, we did not obtain information about the actual layout and characteristics in the office environment. According to Mihaly Csikszentmihalyi (in Schmitt, 1999), during the convergent phase in creativity, the physical environment is required to be familiar, comfortable, as for the divergent phase, it is better to have beautiful and novel surroundings. Bernd Schmitt (1999) also mentioned that environments might also have to be exciting, intense and almost overwhelming to enhance creative thinking, depending on the profession and problem domain. It is suggested that future research can explore how different workspaces were being utilized, and how these different environments can support cognitive process (Kristensen, 2004) with alternative models.

\section{Conclusions}

Office environment plays a central role in the work experience. Although there is no consensus upon which type of workspace is the most appropriate, regardless of the settings, people's intentions, actions and the meaning they ascribe to their job behavior cannot be considered apart from their environments (Carnevale, 1992). Our study extends previous interest on how physical work environment affects creativity, and offers a model where activated positive mood mediates between this relationship. To conclude, with increasing demand for creativity as a critical job outcome in the knowledge-driven economy, strategically, the design of physical work environment should be considered as an important factor in fostering creativity.

\section{Appendix}

Spatial organization items:

1. There are varying working environment to support various tasks and activities.

2. The floor configuration provides opportunities for colleague interaction. 
3. There are supporting areas in my work environment.

4. There are informal spaces in my work environment.

Architectonic details items:

1. There are ornaments or materials to.

2. My workspace is very colourful.

3. My workspace is very comfortable.

\section{References}

Aiello, J. R., DeRisi, D. T., Epstein, Y. M., \& Karlin, R. A. (1977). Crowding and the role of interpersonal distance preference. Sociometry, 40(3), 271-282. https://doi.org/10.2307/3033534

Amabile, T. M. (1988). A model of creativity and innovation in organizations. In B. M. Staw \& L. L. Cummings (Eds.), Research In Organizational Behavior, 10, 123-167. Greenwich, CT: JAI Press.

Amabile, T. M. (1996). Creativity in context. Boulder, CO: Westview Press.

Amabile, T. M. (1983). The social psychology of creativity: a componential conceptualization. Journal of Personality and Social Psycology, 45(2), 357-376. https://doi.org/10.1037/0022-3514.45.2.357

Amabile, T. M., Barsade, S. G., Mueller, J. S., \& Staw, B. M. (2005). Affect and creativity at work. Administrative Science Quarterly, 50(3), 367-403. https://doi.org/10.2189/asqu.2005.50.3.367

Amabile, T. M., \& Gryskiewicz, N. D. (1989). The creative environment scales: work environment inventory. Creativity Research Journal, 2(4), 231-253. https://doi.org/10.1080/10400418909534321

Ashby, F. G., Isen, A. M., \& Turken, A. U. (1999). A neuropsychological theory of positive affect and its influence on cognition. Psychological Review, 106(3), 529-550.

ttps://doi.org/10.1037/0033-295X.106.3.529

Axtell, C. M., Holman, D. J., Unsworth, K. L., Wall, T. D., Waterson, P. E., \& Harrington, E. (2000). Shopfloor innovation: facilitating the suggestion and implementation of ideas. Journal of Occupational and Organizational Psychology, 73(3), 265-285. https://doi.org/10.1348/096317900167029

Baas, M., Dreu, de C. K. W., \& Nijstad, B. A. (2008). A meta-analysis of 25 years of mood-creativity research: hedonic tone, activation, or regulatory focus? Psychological Bulletin, 134(6), 779-806. https://doi.org/10.1037/a0012815

Baldassare, M. (1978). Human spatial behavior. Annual Review of Sociology, 4, 29-56. https://doi.org/10.1146/annurev.so.04.080178.000333

Barron, F. (1969). Creative person and creative process. New York: Holt, Rinehart and Winston.

Becker, F., \& Steele, F. (1990). The total workplace. Facilities, 8(3), 9-14. https://doi.org/10.1108/EUM0000000002099

Becker, F., \& Steele, F. (1995). Workplace by design: mapping the high-performance workscape. San Francisco, CA: Jossey-Bass Publishers.

Beghetto, R. A., \& Kaufman, J. C. (2009). Do we all have multicreative potential? ZDM: The International Journal on Mathematics Education, 41(1-2), 39-44. https://doi.org/10.1007/s11858-008-0143-7

Berquist, J. L. (1999, 20 November). Theories of space and construction of the ancient world: constructs of the social and cultural worlds of antiquity group. Paper Presented at AAR/SBL Annual Meeting. Boston, Massachusetts, United States [unpublished source].

Bindl, U. K., \& Parker, Sh. K. (2012). Affect and employee proactivity: a goal-regulatory perspective. In N. M. Ashkanasy, Ch. E. J. Härtel, \& W. J. Zerbe, (Series Eds.), Research on Emotion in Organizations, 8, 225-255. Experiencing and managing emotions in the workplace. N. M. Ashkanasy, Ch. E. J. Härtel, \& W. J. Zerbe (Eds.). Bingley: Emerald Group Publishing Limited. 
Bissing-Olson, M. J., Iyer, A., Fielding, K. S., \& Zacher, H. (2013). Relationships between daily affect and pro-environmental behavior at work: the moderating role of pro-environmental attitude. Journal of Organizational Behavior, 34(2), 156-175. https://doi.org/10.1002/job.1788

Bledow, R., Rosing, K., \& Frese, M. (2013). A dynamic perspective on affect and creativity. Academy of Management Journal, 56(2), 432-450. https://doi.org/10.5465/amj.2010.0894

Brief, A. P., Burke, M. J., George, J. M., Robinson, B. S., \& Webster, J. (1988). Should negative affectivity remain an unmeasured variable in the study of job stress? Journal of Applied Psychology, 73(2), 193-198. https://doi.org/10.1037/0021-9010.73.2.193

Brill, M., Margulis, S. T., \& Konar, E. (1984). Using office design to increase productivity. Vol. 1. Buffalo, N.Y.: Workplace Design and Productivity, Inc.

Brill, M., Margulis, S. T., \& Konar, E. (1985). Using office design to increase productivity, 2. Buffalo, N.Y.: Workplace Design and Productivity, Inc.

Burke, M. J., Brief, A. P., George, J. M., Roberson, L., \& Webster, J. (1989). Measuring affect at work: confirmatory analyses of competing mood structures with conceptual linkage to cortical regulatory systems. Journal of Personality and Social Psychology, 57(6), 1091-1102. https://doi.org/10.1037/0022-3514.57.6.1091

Carnevale, D. G. (1992). Physical settings of work: a theory of the effects of environmental form. Public Productivity \& Management Review, 15(4), 423-436. https://doi.org/10.2307/3380628

Caroff, X., \& Lubart, T. (2012). Multidimensional approach to detecting creative potential in managers. Creativity Research Journal, 24(1), 13-20. https://doi.org/10.1080/10400419.2012.652927

Coradi, A., Heinzen, M., \& Boutellier, R. (2015). A longitudinal study of workspace design for knowledge exploration and exploitation in the research and development process. Creativity and Innovation Management, 24(1), 55-71. https://doi.org/10.1111/caim.12099

Csikszentmihalyi, M. (2003). Good business: leadership, flow, and the making of meaning. New York, NY: Viking.

Davis, M. C., Leach, D. J., \& Clegg, Ch. W. (2011). The physical environment of the office: contemporary and emerging issues. In G. P. Hodgkinson \& J. K. Ford (Eds.), International Review of Industrial and Organizational Psychology, 26, 193-237. Hoboken, NJ: John Wiley \& Sons, Ltd. https://doi.org/10.1002/9781119992592.ch6

Davis, T. R. V. (1984). The influence of the physical environment in offices. Academy of Management Review, 9(2), 271-283. https://doi.org/10.5465/amr.1984.4277654

Dreu, de C. K. W., Baas, M., \& Nijstad, B. A. (2008). Hedonic tone and activation level in the moodcreativity link: toward a dual pathway to creativity model. Journal of Personality and Social Psychology, 94(5), 739-756. https://doi.org/10.1037/0022-3514.94.5.739

Dul, J., Ceylan, C., \& Jaspers, F. (2011). Knowledge workers' creativity and the role of the physical work environment. Human Resource Management, 50(6), 715-734. https://doi.org/10.1002/hrm.20454

Duffy, F. (1997). The new office. London: Conran Octopus.

Elsbach, K. D., \& Pratt, M. G. (2007). The physical environment in organizations. In J. P. Walsh \& A. P. Brief (Eds.), The academy of management annals, 1, 181-224. Abingdon: Routledge. https://doi.org/10.5465/078559809

Feldman Barrett, L., \& Russell, J. A. (1998). Independence and bipolarity in the structure of current affect. Journal of Personality and Social Psychology, 74(4), 967-984. https://doi.org/10.1037/0022-3514.74.4.967

Fisher, C. D., \& Ashkanasy, N. M. (2000). The emerging role of emotions in work life: an introduction. Journal of Organizational Behaviour, 21(2), 123-129. https://doi.org/10.1002/(SICI)1099-1379(200003)21:2<123::AID-JOB33>3.0.CO;2-8

Florida, R. (2002). The rise of the creative class: and how it's transforming work, leisure, community and 
everyday life. New York: Basic Books.

Frijda, N. H. (1988). The laws of emotion. American Psychologist, 43(5), 349-358. https://doi.org/10.1037/0003-066X.43.5.349

Gifford, R. (1988). Light, decor, arousal, comfort and communication. Journal of Environmental Psychology, 8(3), 177-189. https://doi.org/10.1016/S0272-4944(88)80008-2

George, J. M., \& Zhou, J. (2007). Dual tuning in a supportive context: joint contributions of positive mood, negative mood, and supervisory behaviors to employee creativity. Academy of Management Journal, 50(3), 605-622. https://doi.org/10.5465/amj.2007.25525934

George, J. M., \& Zhou, J. (2002). Understanding when bad moods foster creativity and good ones don't: the role of context and clarity of feelings. Journal of Applied Psychology, 87(4), 687-697. https://doi.org/10.1037/0021-9010.87.4.687

Greene, C., \& Myerson, J. (2011). Space for thought: designing for knowledge workers. Facilities, 29(1/2), 19-30. https://doi.org/10.1108/02632771111101304

Guilford, J. P. (1967). Creativity: yesterday, today and tomorrow. Journal of Creative Behavior, 1(1), 3-14. https://doi.org/10.1002/j.2162-6057.1967.tb00002.x

Haner, U.-E. (2005). Spaces for creativity and innovation in two established organizations. Creativity and Innovation Management, 14(3), 288-298. https://doi.org/10.1111/j.1476-8691.2005.00347.x

Hao, N., Xue, H., Yuan, H., Wang, Q., \& Runco, M. A. (2017). Enhancing creativity: proper body posture meets proper emotion. Acta Psychologica, 173, 32-40. https://doi.org/10.1016/j.actpsy.2016.12.005

Hedge, A. (1982). The open-plan office: a systematic investigation of employee reactions to their work environment. Environment and Behavior, 14(5), 519-542. https://doi.org/10.1177/0013916582145002

Hemlin, S., Allwood, C. M., \& Martin, B. R. (2008). Creative knowledge environments. Creativity Research Journal, 20(2), 196-210. https://doi.org/10.1080/10400410802060018

Hennessey, B. A., \& Amabile, T. M. (2010). Creativity. Annual Review of Psychology, 61, 569-598. https://doi.org/10.1146/annurev.psych.093008.100416

Hirt, E. R. (1999). Mood. In M. A. Runco \& S. R. Pritzker (Eds. in Chief), Encyclopedia of Creativity, 2, 241-250. San Diego: Academic Press.

Isen, A. M. (2000). Some perspectives on positive affect and self-regulation. Psychological Inquiry, 11(3), 184-187.

Isen, A. M., Daubman, K. A., \& Nowicki, G. P. (1987). Positive affect facilitates creative problem solving. Journal of Personality and Social Psychology, 52(6), 1122-1131.

https://doi.org/10.1037/0022-3514.52.6.1122

Janssen, O. (2000). Job demands, perceptions of effort-reward fairness and innovative work behaviour. Journal of Occupational and Organizational Psychology, 73(3), 287-302. https://doi.org/10.1348/096317900167038

Jo Hatch, M. (1987). Physical barriers, task characteristics, and interaction activity in research and development firms. Administrative Science Quarterly, 32(3), 387-399. https://doi.org/10.2307/2392911

Jung, D. I. (2001). Transformational and transactional leadership and their effects on creativity in groups. Creativity Research Journal, 13(1), 185-195. https://doi.org/10.1207/S15326934CRJ1302_6

Kallio, T. J., Kallio, K.-M., \& Blomberg, A. J. (2015). Physical space, culture and organisational creativity - a longitudinal study. Facilities, 33(5/6), 389-411. https://doi.org/10.1108/F-09-2013-0074

Kaplan, S., \& Kaplan, R. (2009). Creating a larger role for environmental psychology: the reasonable person model as an integrative framework. Journal of Environmental Psychology, 29(3), 329-339. https://doi.org/10.1016/j.jenvp.2008.10.005

Kaye, S. M., \& Murray, M. A. (1982). Evaluations of an architectural space as a function of variations 
in furniture arrangement, furniture density, and windows. Human Factors: The Journal of the Human Factors and Ergonomics Society, 24(5), 609-618. https://doi.org/10.1177/001872088202400511

Kelley, T., \& Littman, J. (2005). The ten faces of innovation: IDEO's strategies for beating the devil's advocate and driving creativity throughout your organization. New York: Currency/Doubleday.

Knez, I. (2001). Effects of colour of light on nonvisual psychological processes. Journal of Environmental Psychology, 21(2), 201-208. https://doi.org/10.1006/jevp.2000.0198

Kopec, D. (2006). Environmental psychology for design. New York: Fairchild Publications, Inc.

Kristensen, T. (2004). The physical context of creativity. Creativity and Innovation Management, 13(2), 89-96. https://doi.org/10.1111/j.0963-1690.2004.00297.x

Küller, R., Ballal, S., Laike, Th., Mikellides, B., \& Tonello, G. (2006). The impact of light and colour on psychological mood: a cross-cultural study of indoor work environments. Ergonomics, 49(14), 1496-1507. https://doi.org/10.1080/00140130600858142

Küller, R., \& Mikellides, B. (1993). Simulated studies of color, arousal, and comfort. In R. W. Marans \& D. Stokols (Eds.), Environmental Simulation: Research and Policy Issues (pp. 163-190). New York: Springer Science+Business Media. https://doi.org/10.1007/978-1-4899-1140-7_7

Kwallek, N., \& Lewis, C. M. (1990). Effects of environmental colour on males and females: a red or white or green office. Applied Ergonomics, 21(4), 275-278. https://doi.org/10.1016/0003-6870(90)90197-6

Larsen, L., Adams, J., Deal, B., Kweon, B. S., \& Tyler, E. (1998). Plants in the workplace: the effects of plant density on productivity, attitudes, and perceptions. Environment and Behavior, 30(3), 261-281. https://doi.org/10.1177/001391659803000301

Larsen, R. J., \& Diener, E. (1992). Promises and problems with the circumplex model of emotion. In M. S. Clark (Ed.), Review of Personality and Social Psychology, 13, 25-59. Thousand Oaks, CA: Sage Publications, Inc.

Leather, Ph., Beale, D., Santos, A., Watts, J., \& Lee, L. (2003). Outcomes of environmental appraisal of different hospital waiting areas. Environment and Behavior, 35(6), 842-869. https://doi.org/10.1177/0013916503254777

Leonard, D., \& Swap, W. (1999). When sparks fly: harnessing the power of group creativity. Boston: Harvard Business School Press.

Lubart, T. (2003). Psychologie de la créativité. Series: Cursus. Paris: Armand Colin.

Lubart, T., \& Guignard, J.-H. (2004). The generality-specificity of creativity: a multivariate approach. In R. J. Sternberg, E. L. Grigorenko, \& J. L. Singer (Eds.), Creativity: From Potential to Realization (pp. 43-56). Washington, DC: American Psychological Association. https://doi.org/10.1037/10692-004

Lyubomirsky, S., King, L., \& Diener, E. (2005). The benefits of frequent positive affect: does happiness lead to success? Psychological Bulletin, 131(6), 803-855. https://doi.org/10.1037/0033-2909.131.6.803

MacKinnon, D. W. (1962). The nature and nurture of creative talent. American Psychologist, 17(7), 484-495. https://doi.org/10.1037/h0046541

Madrid, H. P., Patterson, M. G., Birdi, K. S., Leiva, P. I., \& Kausel, E. E. (2014). The role of weekly high-activated positive mood, context, and personality in innovative work behavior: a multilevel and interactional model. Journal of Organizational Behavior, 35(2), 234-256. https://doi.org/10.1002/job.1867

Magadley, W., \& Birdi, K. (2009). Innovation labs: an examination into the use of physical spaces to enhance organizational creativity. Creativity and Innovation Management, 18(4), 315-325. https://doi.org/10.1111/j.1467-8691.2009.00540.x

Martens, Y. (2011). Creative workplace: instrumental and symbolic support for creativity. Facilities, 29(1/2), 63-79. https://doi.org/10.1108/02632771111101331

Mattila, A. S., \& Wirtz, J. (2001). Congruency of scent and music as a driver of in-store evaluations and behavior. Journal of Retailing, 77(2), 273-289. https://doi.org/10.1016/S0022-4359(01)00042-2 
May, D. R., Oldham, G. R., \& Rathert, Ch. (2005). Employee affective and behavioral reactions to the spatial density of physical work environments. Human Resource Management, 44(1), 21-33. https://doi.org/10.1002/hrm.20038

Mitchell McCoy, J. (2005). Linking the physical work environment to creative context. Journal of Creative Behavior, 39(3), 167-189. https://doi.org/10.1002/j.2162-6057.2005.tb01257.x

Mitchell McCoy, J. (2002). Work environments. In R. B. Bechtel \& A. Churchman (Eds.), Handbook of Environmental Psychology (pp. 443-460). New York: John Wiley \& Sons, Inc.

Mitchell McCoy, J., \& Evans, G. W. (2002). The potential role of the physical environment in fostering creativity. Creativity Research Journal, 14(3-4), 409-426. https://doi.org/10.1207/S15326934CRJ1434_11

McElroy, J. C., \& Morrow, P. C. (2010). Employee reactions to office redesign: a naturally occurring quasi-field experiment in a multi-generational setting. Human Relations, 63(5), 609-636. https://doi.org/10.1177/0018726709342932

Moultrie, J., Nilsson, M., Dissel, M., Haner, U.-E., Janssen, S., \& Lugt, van der R. (2007). Innovation spaces: towards a framework for understanding the role of the physical environment in innovation. Creativity and Innovation Management, 16(1), 53-65. https://doi.org/10.1111/j.1467-8691.2007.00419.x

Mumford, M. D., \& Licuanan, B. (2004). Leading for innovation: conclusions, issues, and directions. The Leadership Quarterly, 15(1), 163-171. https://doi.org/10.1016/j.leaqua.2003.12.010

Muthén, L. K., \& Muthén, B. O. (1998). Mplus: statistical analysis with latent variables. User's guide. Los Angeles, CA: Muthén \& Muthén.

Oksanen, K., \& Ståhle, P. (2013). Physical environment as a source for innovation: investigating the attributes of innovative space. Journal of Knowledge Management, 17(6), 815-827. https://doi.org/10.1108/JKM-04-2013-0136

Ree, van H. J. (2002). The added value of office accommodation to organisational performance. Work Study, 51(7), 357-363. https://doi.org/10.1108/00438020210449012

Rompay, van Th. J. L., \& Jol, T. (2016). Wild and free: unpredictability and spaciousness as predictors of creative performance. Journal of Environmental Psychology, 48, 140-148. https://doi.org/10.1016/j.jenvp.2016.10.001

Runco, M. A. (2004). Everyone has creative potential. In R. J. Sternberg, E. L. Grigorenko, \& J. L. Singer (Eds.), Creativity: from potential to realization (pp. 21-30). Washington, DC: American Psychological Association. https://doi.org/10.1037/10692-002

Runco, M. A., \& Jaeger, G. J. (2012). The standard definition of creativity. Creativity Research Journal, 24(1), 92-96. https://doi.org/10.1080/10400419.2012.650092

Russell, J. A. (1980). A circumplex model of affect. Journal of Personality and Social Psychology, 39(6), 1161-1178. https://doi.org/10.1037/h0077714

Russell, J. A. (2003). Core affect and the psychological construction of emotion. Psychological Review, 110(1), 145-172. https://doi.org/10.1037/0033-295X.110.1.145

Saavedra, R., \& Earley, P. Ch. (1991). Choice of task and goal under conditions of general and specific affective inducement. Motivation and Emotion, 15(1), 45-65. https://doi.org/10.1007/BF00991475

Sailer, K. (2011). Creativity as a social and spatial process. Facilities, 29(1/2), 6-18. https://doi.org/10.1108/02632771111101296

Schmitt, B. H. (1999). Experiential marketing: how to get customers to sense, feel, think, act, relate to your company and brand. New York: The Free Press.

Seo, M.-G., Bartunek, J. M., \& Feldman Barrett, L. (2010). The role of affective experience in work motivation: test of a conceptual model. Journal of Organizational Behavior, 31(7), 951-968. 
Shalley, Ch. E. (1991). Effects of productivity goals, creativity goals, and personal discretion on individual creativity. Journal of Applied Psychology, 76(2), 179-185.

https://doi.org/10.1037/0021-9010.76.2.179

Shalley, Ch. E., \& Gilson, L. L. (2004). What leaders need to know: a review of social and contextual factors that can foster or hinder creativity. The Leadership Quarterly, 15(1), 33-53. https://doi.org/10.1016/j.leaqua.2003.12.004

Shalley, Ch. E., Gilson, L. L., \& Blum, T. C. (2009). Interactive effects of growth need strength, work context, and job complexity on self-reported creative performance. Academy of Management Journal, 52(3), 489-505. https://doi.org/10.5465/amj.2009.41330806

Shalley, Ch. E., Gilson, L. L., \& Blum, T. C. (2000). Matching creativity requirements and the work environment: effects on satisfaction and intentions to leave. Academy of Management Journal, 43(2), 215-223. https://doi.org/10.5465/1556378

Shalley, Ch. E., \& Oldham, G. R. (1997). Competition and creative performance: effects of competitor presence and visibility. Creativity Research Journal, 10(4), 337-345.

https://doi.org/10.1207/s15326934crj1004_5

Shalley, Ch. E., Zhou, J., \& Oldham, G. R. (2004). The effects of personal and contextual characteristics on creativity: where should we go from here? Journal of Management, 30(6), 933-958. https://doi.org/10.1016/j.jm.2004.06.007

Shin, Sh. J., \& Zhou, J. (2003). Transformational leadership, conservation, and creativity: evidence from Korea. Academy of Management Journal, 46(6), 703-714. https://doi.org/10.5465/30040662

Sosik, J. J. (1997). Effects of transformational leadership and anonymity on idea generation in computer-mediated groups. Group \& Organization Management, 22(4), 460-487. https://doi.org/10.1177/1059601197224004

Sosik, J. J., Kahai, S. S., \& Avolio, B. J. (1998). Transformational leadership and dimensions of creativity: motivating idea generation in computer-mediated groups. Creativity Research Journal, 11(2), 111-121. https://doi.org/10.1207/s15326934crj1102_3

Steele, F. (1986). Making and managing high-quality workplaces: an organizational ecology. New York: Teachers College Press.

Steidle, A., \& Werth, L. (2013). Freedom from constraints: darkness and dim illumination promote creativity. Journal of Environmental Psychology, 35, 67-80. https://doi.org/10.1016/j.jenvp.2013.05.003

Sternberg, R. J., \& Lubart, T. I. (1995). Defying the crowd: cultivating creativity in a culture of conformity. New York, NY: The Free Press.

Sternberg, R. J., \& Lubart, T. I. (1996). Investing in creativity. American Psychologist, 51(7), 677-688. https://doi.org/10.1037/0003-066X.51.7.677

Stokols, D., Clitheroe, Ch., \& Zmuidzinas, M. (2002). Qualities of work environments that promote perceived support for creativity. Creativity Research Journal, 14(2), 137-147. https://doi.org/10.1207/S15326934CRJ1402_1

Stone, N. J., \& English, A. J. (1998). Task type, posters, and workspace color on mood, satisfaction, and performance. Journal of Environmental Psychology, 18(2), 175-185. https://doi.org/10.1006/jevp.1998.0084

Stone, N. J., \& Irvine, J. M. (1994). Direct or indirect window access, task type, and performance. Journal of Environmental Psychology, 14(1), 57-63. https://doi.org/10.1016/S0272-4944(05)80198-7

Staw, B. M., Sutton, R. I., \& Pelled, L. H. (1994). Employee positive emotion and favorable outcomes at the workplace. Organization Science, 5(1), 51-71. https://doi.org/10.1287/orsc.5.1.51

Sullivan, C. (1991). Employee comfort, satisfaction and productivity: recent efforts at Aetna. In S. Sauter, M. Dainoff, \& M. Smith (Eds.), Promoting health and productivity in the computerized officel models of successful ergonomic interventions (pp. 28-48). Bristol, PA: Taylor \& Francis/Hemisphere. 
Tellegen, A., Watson, D., \& Clark, L. A. (1999). On the dimensional and hierarchical structure of affect. Psychological Science, 10(4), 297-303. https://doi.org/10.1111/1467-9280.00157

Thompson, K. (Ed.). (2003). The early sociology of management and organizations, V. In F. J. Roethlisberger \& W. J. Dickson (Eds.), Management and the worker. London and New York: Routledge.

Tierney, P., \& Farmer, S. M. (2002). Creative self-efficacy: its potential antecedents and relationship to creative performance. The Academy of Management Journal, 45(6), 1137-1148. https://doi.org/10.2307/3069429

Torrance, E. P. (1966). Torrance tests of creative thinking: norms-technical manual. Research edition. Verbal tests, forms A and B. Figural tests, forms A and B. Princeton: Personnel Press.

Turner Parish, J., Berry, L. L., \& Lam, Sh. Y. (2008). The effect of the servicescape on service workers. Journal of Service Research, 10(3), 220-238. https://doi.org/10.1177/1094670507310770

Vischer, J. C. (1989). Environmental quality in offices. New York, NY: John Wiley \& Sons Inc.

Vischer, J. C. (2007). The effects of the physical environment on job performance: towards a theoretical model of workspace stress. Stress and Health, 23(3), 175-184. https://doi.org/10.1002/smi.1134

Vischer, J. C. (2008). Towards an environmental psychology of workspace: how people are affected by environments for work. Architectural Science Review, 51(2), 97-108. https://doi.org/10.3763/asre.2008.5114

Vischer, J. C., \& Fischer, G.-N. (2005). User evaluation of the work environment: a diagnostic approach. Le Travail Humain, 68(1), 73-96. https://doi.org/10.3917/th.681.0073

Warr, P., Bindl, U. K., Parker, Sh. K., \& Inceoglu, I. (2014). Four-quadrant investigation of job-related affects and behaviours. European Journal of Work and Organizational Psychology, 23(3), 342-363. https://doi.org/10.1080/1359432X.2012.744449

Watson, D. (2000). Mood and temperament. Series: Emotions and Social Behavior. P. Salovey (Series Ed.). New York: The Guilford Press.

Watson, D., \& Tellegen, A. (1985). Toward a Consensual Structure of Mood. Psychological Bulletin, 98(2), 219-235. https://doi.org/10.1037/0033-2909.98.2.219

Weiss, H. M. (2002). Conceptual and empirical foundations for the study of affect at work. In R. G. Lord, R. J. Klimoski, \& R. Kanfer (Eds.), Emotions in the workplace: understanding the structure and role of emotions in organizational behavior (pp. 20-63). San Francisco: Jossey-Bass.

Woodman, R. W., Sawyer, J. E., \& Griffin, R. W. (1993). Toward a theory of organizational creativity. Academy of Management Review, 18(2), 293-321. https://doi.org/10.5465/amr.1993.3997517

Zalesny, M. D., \& Farace, R. V. (1987). Traditional versus open offices: a comparison of sociotechnical, social relations, and symbolic meaning perspectives. Academy of Management Journal, 30(2), 240-259. https://doi.org/10.2307/256272

Zelinsky, M. (1998). New workplaces for new workstyles. New York: McGraw-Hill.

Zhang, X., \& Bartol, K. M. (2010). Linking empowering leadership and employee creativity: the influence of psychological empowerment, intrinsic motivation, and creative process engagement. Academy of Management Journal, 53(1), 107-128. https://doi.org/10.5465/amj.2010.48037118

Zhou, J., \& George, J. M. (2001). When job dissatisfaction leads to creativity: encouraging the expression of voice. Academy of Management Journal, 44(4), 682-696. https://doi.org/10.2307/3069410

Zhou, J., Shin, Sh. J., \& Cannella, Jr. A. A. (2008). Employee self-perceived creativity after mergers and acquisitions: interactive effects of threat-opportunity perception, access to resources, and support for creativity. The Journal of Applied Behavioral Science, 44(4), 397-421.

https://doi.org/10.1177/0021886308328010 


\title{
AR ATVIROJO PLANO BIURŲ APLINKA PALAIKO KŪRYBIŠKUMĄ? POVEIKI DARANTIS SUAKTYVINTAS POZITYVUS NUSITEIKIMAS
}

\author{
Szu-Yin LIN, Hsin-I CHANG
}

\section{Santrauka}

Šiame tyrime nagrinejjama, kaip suvokiamos fizinès biuro aplinkos ypatumai veikia darbuotojų kūrybiškumą, jiems esant pozityviai nusiteikusiems. Remdamiesi atvirojo plano biurų 181 darbuotojo pavyzdžiu nustateme, kad suvokiamos erdvinès organizacijos ypatumams buvo būdingas pozityvus santykis su pačių darbuotojų savojo kūrybiškumo vertinimais, o šiam santykiui netiesioginę įtaką turi pozityvus nusiteikimas. Nors fizinès darbo aplinkos suvokiamos architektūrinès detalès neturi tiesioginio poveikio darbuotojų kūrybiškumui, vis dèlto pozityvus nusiteikimas daro netiesioginị poveikị. Tolesnis tyrimas atskleidè, kad suaktyvintas pozityvus nusiteikimas turi reikšmingą itaką santykiui tiek tarp fizinès darbo aplinkos ypatumų, tiek tarp darbuotojų kūrybiškumo, o nesuaktyvintas pozityvus nusiteikimas neturejo didelès reikšmės poveikio atžvilgiu. Darbuotojai suprato, kad fizinė darbo aplinka, kuri sudaro sąlygas kurti ịvairias darbo erdves ir yra tinkamai apipavidalinta, labai tikètina, jog ir sustiprina kūrybiškumą.

Reikšminiai žodžiai: suaktyvintas pozityvus nusiteikimas, kūrybiškumas, nusiteikimas, fizinè darbo aplinka. 